\title{
Visible Subjects in the Countryside
}

But after I became a revolutionary and lived with workers and peasants and with soldiers of the revolutionary army... I came to feel that compared with the workers and peasants the unremoulded intellectuals were not clean and that, in the last analysis, the workers and peasants were the cleanest people and, even though their hands were soiled and their feet smeared with cowdung, they were really cleaner than the bourgeois and petty-bourgeois intellectuals. That is what is meant by a change in feelings, a change from one class to another. If our writers and artists who came from the intelligentsia want their works to be well received by the masses, they must change and remould their thinking and their feelings. Without such a change, without such remoulding, they can do nothing well and will be misfits.

- MAO ZEDONG, SPEECH AT THE YAN'AN FORUM ON LITERATURE AND $A R T, 1942$

In the spring of 1939 Ma Hong (1920-2007), a 19-year-old, had an unforgettable encounter with Mao Zedong (1893-1976). Ma had recently joined the CCP and was studying at the Academy of Marxist-Leninist Studies (Malie xueyuan) in Yan'an, an impoverished town in northwestern China that housed the party's headquarters. The academy was set up across a row of loess caves traditionally used as residential spaces. It offered what the party leadership regarded as advanced theoretical and political training to select party members, some of whom had studied in college and even overseas. The training was designed to prepare these individuals for positions of authority in the ongoing project of Chinese Communism. On the day of the encounter, Mao arrived at the academy and paid a surprise visit to an office shared by students, before giving a prescheduled speech. As the party secretary of his class, Ma answered the Chairman's questions about life on campus on behalf of delighted classmates. Mao then inquired about the teenager's own background. Ma replied humbly that he had little formal education and therefore his "level of knowledge and learning" was not high, but he also stressed that he relished every opportunity to read books and newspapers. Before leaving the office, Mao excited 
the students further with three pieces of impromptu calligraphy that validated their sacrifices and hard work. One of these said "Reading books is good."

Based on his daughter's recollection, Ma came from a poor rural family but was not as undereducated as he indicated to the Chairman. Although his parents did not send him to school, Ma learned to read and write so painlessly as a child that a village elder paid him to compile the local lineage genealogy and the county gazetteer. Ma used the earnings to attend primary school and completed it in fewer than four years. The school principal promptly hired this outstanding graduate to teach senior primary classes. Fellow villagers also considered Ma exceptionally talented, and helped him land a desk job in a railway management bureau when he was only $16 .^{2}$ His precociousness would be recognized at the academy. Within two years of meeting Mao, Ma penned two important essays that laid out the rationale, approach, and procedure for investigating and evaluating the class backgrounds and characters of party cadres, a political as well as literary achievement, and all the more so for a young adult. ${ }^{3}$ In front of Mao, however, Ma did not disclose that he was a superior writer or former schoolteacher, or other parts of his life that would have led the Chairman to see him as an "intellectual." Ma's reaction suggests that he understood something unconventional, and even paradoxical, about the self-presentation of educated people under Chinese Communism. He recognized this, moreover, before others did during the famous 1942 Yan'an Forum on Literature and Art, when Mao put down "bourgeois and petty-bourgeois intellectuals," all the while flaunting his own literary achievement, aesthetic sensitivity, and cultural refinement within the rural town.

This chapter describes the rise of a visible, sizable, and stigmatized population of "intellectuals" and the spread of the institutions of workplace management by party cadres, ideological reeducation, and mass surveillance in Yan'an. Within the town, Chinese Communism enjoyed much-needed stability and security after a tumultuous decade marked by growth, fragmentation, and carnage. The party elites accepted Mao's leadership, however grudgingly, and his view that the revolutionary project badly needed the knowledge and skills obtainable from intellectuals even though they were untrustworthy. Exploiting the symbolic power and mobilization skills it had acquired since the early 1920s, the party recruited large numbers of relatively educated people to Yan'an. Ensuing partition of space, division of work, establishment of organizations, and other social and physical rearrangements engendered an abundance of signs and cues that reinforced the top-down representation of the newcomers as intellectuals. The virtually coercive Rectification Campaign (Zhengfeng yundong) (1942-1944) initiated by Mao normalized not only his view of the intellectual but also the triple institutions mentioned above. Instruction, confession, supervision, and other measures turned the newcomers and others into usable but unreliable "intellectuals" as well as subjects of education and objects of knowledge. Like the emergence of the intellectual classification shortly after the CCP's founding and the subsequent normalization of 
the classification under the PRC, the pursuit of revolutionary authority by educated party members over others who were also educated was a central dynamic in the spread of the marker.

Although the above objectification of the intellectual occurred in a relatively enclosed environment organized by the CCP, it was not a uniform, clear-cut, or one-sided process. Conceptually, the party's definition of intellectuals-as a population of educated people situated between the exploiting and the exploited classes-did not capture the complexity of the backgrounds of the educated persons involved, some of whom could be counted as "workers," "poor peasants," or other kinds of subject under the official schema of classes. Organizationally, the hierarchical structure underlying workplace management by party cadres, ideological reeducation, mass surveillance, and other political control mechanisms had uneven impact on social identity, as they tended to spotlight some as "intellectuals" more than others who were equally, if not more, educated. Furthermore, because the intellectual classification was laden with both positive and negative meanings, individual negotiations aimed at gaining authority and opportunity within the revolutionary town and minimizing stigmatization, like the conduct of Mao and Ma noted above, created ambiguity and difficulty in everyday identification. In fact, as Chinese Communism expanded, it furnished pathways for upper mobility, job change, and training that enabled many educated persons to improve their revolutionary images as well as to benefit from their academic or professional training. The revolutionary project created a myriad of social and ideological positions and stimulated multiple strategies of "position-taking" 4 that muddied the boundaries of the population of intellectuals that emerged.

This chapter therefore gives an account of the evolution of the intellectual from a classification of people in early CCP ideology to the social identity of tens of thousands of revolutionaries in a rural society. It illustrates the corresponding transformation of institutions, organizations, and relations as well as personal values, interests, and habits. Research on Yan'an has studied how the party leadership set up the town and the implications for Chinese Communism after 1949. ${ }^{5}$ It has explored how writers, artists, and others as intellectuals supported or challenged the project. ${ }^{6}$ Only limited attention has been given to arguably the most important achievement of Chinese Communism up till then, that is, what Pierre Bourdieu and Loic Wacquant would call the "collective work of construction of social reality" led by the party. ${ }^{7}$ Yan'an revolutionaries came to apprehend, characterize, and distinguish themselves and others as class subjects based on a Marxian view. ${ }^{8}$ At the heart of this success, this chapter reveals, was the top-down deployment of the "intellectual" marker. The deployment engendered discourses, processes, and relations that profoundly affected the revolutionary project in terms of structure and culture.

Before revisiting life in revolutionary Yan'an, it is necessary to summarize the relations between the intellectual and Chinese Communism from the early 1920 s 
to mid-1930s. I draw attention to four interrelated trends, each of which would intensify within the headquarters town. First, the intellectual became a major classification used by the CCP to categorize and differentiate its members and supporters. Second, party leaders and cadres applied the classification to individuals from a variety of backgrounds, but represented themselves differently even if they were well educated. Third, the classification served as a powerful weapon in power struggles within the party leadership and at lower levels of the party. Fourth, provision of education and employment by the party and its mechanisms of control turned otherwise perfectly ordinary people into politically unreliable "intellectuals." The classification was therefore a foundation of organization, identity, and schism under Chinese Communism before it entered the Yan'an phase.

\section{PRELUDE TO YAN'AN}

Despite their denunciations of the character and politics of the educated, Chen Duxiu, Qu Qiubai, and other early CCP leaders believed that these persons were critical to the development of Chinese Communism. The belief reflected the background of the leaders as May Fourth activists seeking to modernize China as well as their subsequent embrace of the Bolshevik model of socialist development, which stressed use of professional knowledge and skills, especially after the socialist revolution. The Comintern-brokered United Front (1923-1927) between the Guomindang and the CCP provided the leaders with otherwise unavailable opportunities to advance Chinese Communism, with results that further reinforced that belief. Thanks to the work of educated men and sometimes women, CCP influence expanded quickly nationwide, albeit under a dominant partner with no interest in a proletarian revolution. CCP leaders and cadres developed and maintained labor unions and other supportive associations as well as orchestrated and assisted in labor strikes and other protests in Shanghai, Wuhan, Guangzhou, and elsewhere. In rural areas, efforts of propaganda and mobilization led to the formation of peasant associations and to social service reforms, rent and interest reductions, and the execution of landlords. Some leaders and cadres became soldiers and political commissars in the Guomindang military and helped to recruit factory workers and peasants into the forces. During the mid-1920s, CCP membership jumped from under 1,000 in January 1925 to almost 58,00o by April 1927.9

With their increasing exposure to Marxist-Leninist thought, early CCP leaders formally categorized some of the people working for Chinese Communism as intellectuals. In December 1926, the party stated that 60, 12, and 27 percent of its members in four regions (Hunan, Guangdong, Shanghai, and northern China) were respectively "workers, peasants, and intellectuals and others." ${ }^{\circ}$ Four months later, the total number of CCP members who were intellectuals reportedly rose above 11,000. ${ }^{11}$ The figures on intellectuals or other categories of class subjects reported by the party then or later (and many such numbers that appear in this book and 
elsewhere) do not point to any demographic subgroups that existed objectively because of their own characteristics. The figures, instead, were part of the objectifying practice of the CCP and the effort of its elites to remake China according to their image. We do not know the people, criteria, or methods involved in the compilation of those numbers mentioned above. In fact, the party leadership at that same time reported its inability to monitor this nationwide process of classification. ${ }^{12}$ From what we have seen in the last chapter, the local party authorities probably categorized a wide range of personnel as intellectuals, for example, from professors and writers to college students and office clerks. Underlying the numbers was an emerging approach to revolutionary organization based on counting and identifying class subjects in general and intellectuals in particular.

When the Guomindang ended the United Front in 1927 by slaughtering nearly 30,000 CCP members and supporters, the intellectual acquired what would become another enduring feature under Chinese Communism: the classification became a weapon in intraparty struggles. Despite early CCP leaders' anti-intellectual rhetoric, educated people had gained prestige, authority, and opportunities within the revolutionary project. What happened at the Peasant Movement Institute in Guangzhou is an excellent example. Thanks to the United Front, the institute was established in 1924. The CCP elites tightly controlled the institute and used it to produce cadres to support the expansion of Chinese Communism into rural areas. During the institute's three years of operation, its instructors, successful graduates, and students were mostly educated men. ${ }^{13}$ After the United Front debacle, however, political vitriol against "intellectuals" saturated the party, leading to its reorganization as well as an extension of its schema of classes across the teetering project. The new leadership, headed by Qu Qiubai at first and supported by the Comintern, attacked deposed leader Chen Duxiu and other cadres. The leadership alleged that these "petty-bourgeois intellectuals" had dominated "virtually every guiding body" of the party. ${ }^{14}$ "They had not received training in Marxism-Leninism, were ignorant of the experiences of the international proletarian movements, and stood outside the class struggle of the workers and poor peasants. They had not reformed themselves into thorough proletarian revolutionaries. On the contrary, they have brought into the party such qualities as being politically infirm, incomplete, and irresolute in behavior, unorganized in style, together with other habits, temperaments, prejudices and fancies that are typical of petty bourgeois revolutionaries" (emphasis added). ${ }^{15}$ Even before the United Front's collapse, ideological competitions among CCP leaders had been common and sometimes intense. ${ }^{16}$ The denunciations afterward crossed another threshold. Defeated colleagues and former allies were cast as political obstacles, liabilities, and even enemies of Chinese Communism, or no better and sometimes even worse than "intellectuals" outside the party.

When Chinese Communism splintered into rural rebellions shortly thereafter, some CCP leaders and cadres acquired opportunities to solidify their claim of 
transformation to proletarian revolutionaries, the political identity they adopted when attacking other educated people inside or outside the party. During the United Front, hundreds of cadres had gained experience in rural organization and mobilization through the Peasant Movement Institute. They had molded and guided peasant interests, established schools and militias, and built layers of peasant associations across different provinces. ${ }^{17}$ Some of these persons, including Mao Zedong, returned to the countryside in Jiangxi Province and elsewhere afterward and joined forces with local party cadres, many of whom were former students and schoolteachers. Together, they adopted local values, mores, and practices as well as peasant dialects, appearance, and habits, and worked with local strongmen and militia, bandit gangs, sworn brotherhoods, and ordinary villagers. Their newly formed guerilla units defended captured territories, raided landlords' properties, promoted mass uprisings, conducted land reform, and fought against incursions from the Guomindang military. ${ }^{18}$ These party leaders and cadres thus assumed roles, personae, and ways of life dramatically different from those of the leaders or cadres who stayed in urban areas, not to mention the office workers or the college and secondary school students that the party disparaged as petty-bourgeois intellectuals.

Hung-yok Ip's study of Peng Pai (1896-1929) and Mao, both of whom were from well-to-do families and well educated, reveals further how some CCP leaders maneuvered to achieve a proletarian revolutionary identity. Peng and Mao were instrumental in developing the rural strategy of Chinese Communism. Although they touted the revolutionary capacity of poor peasants and farm hands to be even more advanced than that of industrial workers (and thus departed from Marx's and Lenin's teachings), they did not entrust their insurgencies to the peasantry any more than other party leaders handed over the organization of urban struggles to workers. Instead, Peng and Mao portrayed the peasantry as "deficient historical subjects,"19 through exploiting their own symbolic power acquired from revolutionary leadership, urban experience, and privileged education, as well as the elitism of the Confucian tradition and the urban biases of May Fourth activism and Marxist-Leninist thought. Between Peng and Mao, a litany of problems of the peasantry purportedly reflecting values, habits, and ways of life in the countryside was identified as obstacles of the revolutionary project, or timidity, superstition, passivity, pessimism, ignorance, familism, localism, stubbornness, hedonism, incompetence, individualism, and lack of spirit, discipline, and organization. ${ }^{20}$ Like the intellectual, the peasant became another figure that party leaders adapted from conventional and contemporary discourses and reintroduced into Chinese Communism to elevate their own status and authority, or consecrate themselves as proletarian revolutionaries.

As the CCP's rural strategy grew by leaps and bounds during the late 1920 s and early 1930s, the use of the intellectual classification as a weapon in intraparty struggles intensified due to policy change and local conflict. After the United Front 
debacle, the CCP leadership, as noted earlier, demanded removals of "petty-bourgeois intellectuals" from positions of authority within the party. The leadership wanted "extensive appointment of workers to cadre positions" (ganbu gongrenhua) and recruitment of workers, poor peasants, and rural laborers into the party. ${ }^{21}$ Much research is needed to clarify how local party organizations and members deployed the intellectual marker during this period of Chinese Communism. Still, trends are observable. Within the leadership, educated men continued to dominate policymaking despite elections of former workers to top positions. ${ }^{22}$ At lower levels, attacks against cadres identified as intellectuals assumed unprecedented proportions even as the leadership warned against excessive actions. Educated men exploited the ideological shift to drive out political competitors and challengers, thereby announcing themselves essentially as proletarian revolutionaries. Some cadres relied on their touted worker backgrounds to attack colleagues whom they accused of being untrustworthy intellectuals. A 1933 CCP report indicates that leaders of the rural bases severely restricted the recruitment of "intellectuals" into the party. ${ }^{23}$ Some local recruits who took up teaching responsibilities quickly became petty-bourgeois intellectuals in the authorities' eyes. ${ }^{24}$ Even former workers and poor peasants who had received schooling organized by the party were sometimes put "on the enemy side of the ledger" by the local authorities. ${ }^{25}$

Across the rural bases, the objectification of the intellectual into embodied class subjects ultimately led to life-and-death consequences. During the early 1930s, fear and paranoia among the leaders about infiltration by Guomindang agents and hence decimation by Guomindang forces intermingled with power struggles and triggered a wave of brutal campaigns against "counterrevolutionaries." Imprisonment, torture, and executions of CCP leaders, cadres, and soldiers became commonplace. According to one estimate, the campaigns caused the deaths of tens of thousands of people. ${ }^{26}$ For example, within the Red Army base that straddled Hubei, Henan, and Anhui Provinces (the E-Yu-Wan base area) and the western Fujian (Minxi) base area, "intellectuals" were designated as targets of investigation, along with former Guomindang personnel and others who had joined the insurgencies. Across the Hunan-Hubei-Jiangxi (Xiang-E-Gan) base area, over 5,000 people, most of them "rich peasants" and "intellectuals," were executed. ${ }^{27} \mathrm{~A}$ former revolutionary remembered that in her Fujian location, "most of those who were intellectuals in their background were reportedly arrested." ${ }^{28}$ How the detained, tortured, or executed intellectuals had been identified in any of the bases remains unclear. Another former revolutionary recalled that "anyone with a pen clipped on the shirt would be considered an intellectual and could face persecution; it was worse for those who wore glasses." ${ }^{29}$ She probably described not so much the fate of the educated party leaders on the site, but what occurred at the rank-and-file level, in which former schoolteachers and secondary school students and even some with a few years of formal education became targets of abuse. 
As fatal and other assaults raged across the rural rebel movements, their growth drew often unsuspecting people into the CCP category of intellectuals. Besides expanding the local Red Army forces and training their members, party leaders sought to develop industry, commerce, and education as well as art, finance, and medicine in the base areas as means to increase the legitimacy and influence of their insurgency. However fragile were the successes of these efforts, they turned many into technicians, artists, journalists, schoolteachers, and so on-or personnel describable as intellectuals from the party's perspective. What happened within the Jiangxi base led by Mao at one point is instructive. A multilevel system of classes, schools, and institutes emerged. Establishments designated as universities (e.g., the Red Army University and the Soviet University) enrolled military and administrative cadres for political and theoretical training. Thousands attended teacher-training classes and courses in finance, nursing, commerce, and drama and then served in those areas. Primary schools, evening schools, and newspaper reading classes offered basic education to children and adults. One estimate put the number of primary school teachers across fourteen counties at 2,535. As well, some rebels took over factories and maintained transportation and communication systems, printing presses, roads, and bridges. Others wrote for newspapers and journals; produced dramas, music, and folksongs; and published books on medicine, law, politics, and other topics. ${ }^{30}$ These and other similar efforts at organization created a pool of revolutionaries who were classifiable by superiors and colleagues and even by themselves as intellectuals.

In sum, although the intellectual had become a major classification of people under Chinese Communism by the mid-1930s, who was recognized locally as an intellectual was not always obvious. Occupation and education, the principal criteria for distinguishing intellectuals expressed in CCP ideology, were important but not decisive factors. Having been a peasant or worker, or having authority within the party, did not always exempt one from the dubious marker. The identification was contextual rather than rule-based, shifting with relations of domination, organizational development, and changes in personal circumstances. Equally important, top-down deployment of the classification led to specific patterns of revolutionary authority, organization, and violence, most prominent of which were the self-consecration of some of the educated rebels as proletarian revolutionaries and their denunciation, exclusion, and even persecution of other educated people as treacherous intellectuals. These ideological and organizational trends would converge in Yan'an-and propel Chinese Communism and its objectification of the intellectual to new heights.

\section{OBJECTIFYING ORGANIZATION OF A TOWN}

Located in Shaanxi Province, Yan'an was a poor and remote town with roughly 3,00o people before CCP leaders established their headquarters there. ${ }^{31}$ When the 
leaders arrived in Yan'an in early 1937, Chinese Communism had already undergone important changes in response to a decade of internal turmoil and external aggression. First, the deadly purges that threatened leader safety and damaged revolutionary morale had been successfully halted; persuasion with moderate coercion, instead, had emerged as the primary means to handle intraparty conflict..$^{32}$ Second, the Red Army forces had been rebuilt with nearby peasant support after their devastating Long March (1934-1935) from central to northwest China to escape annihilation by the Guomindang military. Third, thanks to his military prowess and political skills, Mao had risen to the top of the CCP with a precarious hold on the position. Most important for our purposes, the leadership had adjusted its stance on intellectuals, even though they were still considered flawed in political and moral terms. Mao subsequently articulated the position with the utmost clarity in a 1939 conference of senior party cadres in Yan'an. "The [Chinese Communist] revolution will not triumph without revolutionary intellectuals ... Our army must take in large numbers of such intellectuals. We must convince worker-peasant cadres to accept and not be intimidated by them. Without the help of revolutionary intellectuals, peasants and workers will not improve their skills or knowledge. And we will not be able to rule the nation, the party, or the military. Our government and party offices as well as mass movements must also be set up to attract revolutionary intellectuals." ${ }_{33}$

The CCP's revised approach to intellectuals was consistent with what Lenin promoted before as well as after the October Revolution in Russia, that is, that the socialist revolution and, even more so, the building of a modern socialist society required the active participation of intellectuals. ${ }^{34}$ The party's entrance into the Anti-Japanese War (1937-1945), or resistance against the Japanese invasion of China, reinforced the policy change, as the war would become the primary channel through which the leadership promoted Chinese Communism to a national audience and, in particular, the educated. The new united front that the CCP established with the Guomindang because of the war also facilitated the execution of the revised approach. The political cooperation enabled the CCP to maintain control over Yan'an and the broader Shaanxi-Gansu-Ningxia (Shaan-Gan-Ning) base area as well as to conduct limited but meaningful political activities in Guomindang areas.

The CCP used its networks of members and supporters, military offices in various provinces, and newspaper advertisements to recruit "intellectuals" to come to Yan'an, especially young men and women, whom the Mao regime, like previous leaderships, considered less corrupted by Chinese tradition and capitalist ideology. The party promised the recruits, some of whom were from overseas, accommodation, education, and an active role in war and revolution. ${ }^{35} \mathrm{~A}$ December 1943 party report notes that roughly 40,000 intellectuals had entered Yan'an since the late 1930s. Given the party's broad definition of intellectuals, these newcomers unsurprisingly had a variety of backgrounds. Academically, 30 percent of the 
population had started but not finished junior high school; 21 and 31 percent had completed senior and junior high school, respectively; and 19 percent had postsecondary education. ${ }^{36}$ Most of these recruits were men. A large number were recently secondary school students, to whom the leaders also referred as intellectual youths (zhishi qingnian). There were professional experts such as professors and engineers, literary and art personnel such as playwrights and painters, and technical-support and white-collar workers such as automobile technicians and government clerks. A small number were former soldiers. Some had poor parents, some had had enviable upbringings, and many came from what the party called the petty-bourgeois households of small business owners, schoolteachers, or office workers.

Top-down labeling did not transform these recruits into widely recognized "intellectuals" any more than self-proclamation turned Mao and other CCP leaders into admired proletarian revolutionaries. How the leadership reorganized Yan'an and therefore Chinese Communism to receive the newcomers was crucial. Building on their revolutionary experience and authority, the leaders established an array of institutes bearing names that denoted professional or higher education to absorb the recruits, for example, Women's University of China, Northern Shaanxi Public Academy, Natural Science Research Institute, and Yan'an Ethnology Institute. ${ }^{37}$ Though physically crude and poorly equipped, these institutes usually had their own grounds with residential space allocated nearby. The newcomers were therefore clustered in various parts of the town, separated from the leaders, who lived in relatively spacious compounds that they shared with one another, and from the stationed Red Army troops, who protected Yan'an on its perimeters. Surrounded by poverty and warfare, the faculty and students took classes, read books, and conducted discussions. They attended opening and graduation ceremonies and other activities related to teaching and learning. The education usually lasted from three months to two years and involved various combinations of professional, political, and military training. ${ }^{38}$ Put differently, as the leaders jubilantly proclaimed the arrival of intellectuals, an asset that would strengthen the war effort of the party and its revolutionary capabilities, unprecedented changes overtook work, space, and life in the previously unremarkable town.

How the CCP operated the Lu Xun Academy of Arts (Lu Xun yishu xueyuan) exemplifies the changes in topography and work that spotlighted the newcomers as "intellectuals" as officially claimed. Named after the famous and recently deceased leftist writer, the academy opened its doors in April 1938 inside another newly established institute, the Lu Xun Normal School. Most of the Academy's instructors were writers and artists from Shanghai with no experience in rural insurgency. The students, whose levels of education ranged from primary school to college, were selected because of their interest in the fine arts or performing arts. Climbing enrollment led the authorities to relocate the campus quickly to one of the hills that made up the town. The faculty and students occupied almost twenty 


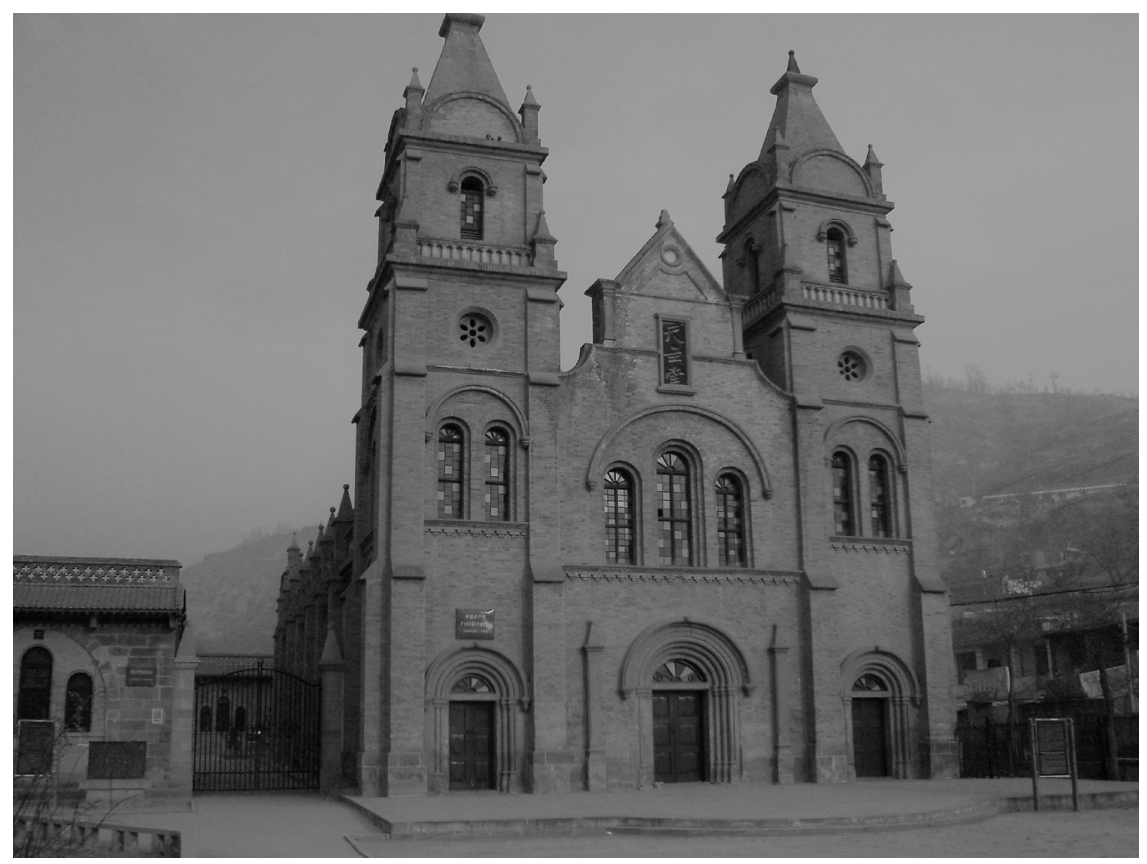

FIGURE 1. Contemporary view of the church that once housed the Lu Xun Academy of Arts.

(Photo by author)

existing loess caves. They dug two more rows of caves, erected a single-story building, and cleared a desolate area for residential, performance, and other purposes. In August 1939 the authorities moved the growing institute farther away from the town center, into an imposing Catholic church with two steeples (see figure 1). Many nearby loess caves were converted for residential use, as were some newly excavated ones. ${ }^{39}$ Work within the academy reflected the leadership's emphasis on both education and revolution. The faculty and students concentrated on teaching and learning art, music, literature, and theater. They distinguished themselves further with use of Western sources, forms, and techniques foreign to the region and unfamiliar to ordinary party cadres and soldiers. They held exhibitions of their work and rehearsals for their productions and performed in front of cadres, soldiers, and students throughout Yan'an..$^{\circ}$

These organizational measures allowed for preservation of the values and habits of the faculty and students acquired outside the rural milieu, the display of which distinguished them further from other Yan'an residents. The notable writer Mao Dun (1896-1981), who taught briefly in the academy during the early 1940s, described faculty residences with admiration: "Because writers and artists live here, each cave is decorated differently and expresses its occupant's unique character. 
Every artist has used his clever inventiveness, his own hands, and extremely crude materials and turned the abode [cave] into an elegantly refined, brightly beautiful, or majestically special place." ${ }^{41}$ In equally visible fashion, some faculty did not wear the military outfit provided to everyone who worked or studied in one or another of the institutes. They donned, instead, fedoras, woolen coats, and other urbanstyle or self-made clothing. Students wore the military outfit, but often with "personal flair." Young women often added a dickey underneath the shirt and pinned colorful swatches on their sleeves and shoes. Some students wore their caps stylishly like berets. Every evening, students and instructors strolled along a nearby riverbank, chatting, making friends, and even falling in love. The popularity of ballroom dancing in revolutionary Yan'an is well documented. Many recruits and even Mao and other party leaders enjoyed this activity. The Lu Xun Academy was an especially popular venue in this regard, hosting at one point dancing parties every Saturday evening. These involved live music by students and decorations by resident artists. ${ }^{42}$

Within the academy and other institutes, relations of domination established by the CCP leadership signaled further that the "intellectuals" who had traveled to Yan'an were different from the revolutionaries who had arrived there earlier. Mao and other party leaders periodically visited the institutes, lectured to the students, and sometimes instructed them on how to overcome their "petty-bourgeois" foibles qua intellectuals. ${ }^{43}$ Party leaders served as heads of the institutes, while veteran cadres filled key administrative positions. These leaders and cadres were mostly well-educated men. In other words, the pattern of authority reflected and reinforced a social division that CCP leaders had been stressing shortly after the party's founding. Or, there were two kinds of educated people in Chinese societythose who had transformed themselves into proletarian revolutionaries and those who had not. For example, the head of the Academy of Marxist-Leninist Studies, Zhang Wentian (1900-1976), had a university-level education and had received theoretical training in Marxism in the Soviet Union. He briefly headed the CCP before Chinese Communism entered its Yan'an phase. ${ }^{44}$ Thanks to his revolutionary experience, authority, and knowledge, this man could confidently claim to be a proletarian revolutionary in front of the faculty and students whom he oversaw. This was probably true, too, of the chief of instruction at the Lu Xun Academy, Xu Yixin (1911-1994), a revolutionary of ten years' standing who had received higher education in the Soviet Union. ${ }^{45}$

For practical and ideological reasons, the Mao leadership used the resources of some of the institutes to train separately newly arrived factory workers and other laborers as well as party cadres from nearby areas and other rural bases. Such visible arrangements further reinforced the official view that the recruits who were former writers or schoolteachers or other kinds of educated persons were "intellectuals." What happened at the Chinese People's Anti-Japanese Resistance University of Military and Politics Affairs (Zhongguo renmin kangri junshi zhengzhi daxue) is 
revealing. This institute, which produced tens of thousands of political, military, and other personnel, divided the constantly changing mix of trainees into brigades (dui). For example, the class that moved into Yanan with the institute in early 1937 had fourteen brigades totaling almost 1,40o people. Senior and ordinary Red Army personnel filled eight of the brigades. The remaining six brigades, including one composed entirely of women, contained mostly recently arrived and relatively educated young people. ${ }^{46}$ Across the institutes, even when the classes involved a mixture of trainees, the heads apparently wanted those who were party cadres or former workers to monitor the behavior of former office workers, college students, and others, and to remain on guard against their supposedly inevitable display of petty-bourgeois or other undesirable ideas and behavior. ${ }^{47}$

Job assignment within Yan'an also had classification impact. To strengthen the Shaan-Gan-Ning base for war and revolution, the CCP leadership used many recruits immediately after their arrival or upon their completion of training to expand education, art, industry, and other sectors. For example, the industrial workforce jumped from under 200 people before 1937 to over 12,000 by $1944^{48}$ The assignments not only turned many into engineers, schoolteachers, journalists, and other kinds of personnel that fit into the party's definition of intellectuals; the development of some of the sectors led to the further clustering of the recruits across the town. A place called Cultural Valley (Wenhua gou) quickly emerged as home to various writers' groups, literary associations, art troupes, a library, and other cultural and educational organizations. On Refreshing Mountain (Qingliang shan), which is a short distance away across the Yan River that runs through the town, the leadership created a media hub that included a news agency, a newspaper, a printing press, a radio station, and a bookstore, among other facilities. The establishment of Yan'an Central Hospital (Yanian zhongyang yiyuan) during the late 1930s illustrates how this approach to job assignment brought those whom the leadership regarded as intellectuals together. The leadership approved the project, chose a site, and appointed as head a bespectacled man who had a doctorate of medicine from the University of Toulouse in France. Others with experience in medicine, nursing, and pharmacology were reassigned to work in the hospital. Physicians and other medical personnel were sent from elsewhere to the establishment, which also recruited and trained newly arrived women with secondary education to become nurses. ${ }^{49}$

\section{NORMALIZATION OF A MARXIAN CLASSIFICATION}

The Rectification Campaign sponsored by Mao was a watershed in the history of Chinese Communism. The campaign began in Yan'an, spread to other CCP bases, and served to consolidate Mao's leadership and strengthen ideological discipline. In their account of the campaign, David Apter and Tony Saich indicate that "a symbolically orchestrated tutelary regime"so built upon textual learning and other 
instructional techniques and backed by coercive power enveloped Yan'an. This regime served to propagate Mao's understanding of revolutionary ethics, Chinese society, and global history and at the same time to delegitimize other political narratives, visions, and strategies. For our purposes, at the center of this achievement was the Mao leadership's deployment of the intellectual classification. In fact, we cannot understand the campaign and its organization any more than we can fathom the topographical and institutional changes mentioned above without taking into account how the classification was used. Mao's view of the intellectual as a usable but unreliable subject defined the character of the campaign, while its success deepened the objectification of the intellectual and left behind an influential organizational legacy.

During Rectification, Mao and his deputies used the intellectual classification as a weapon to attack competitors and potential challengers, just as previous CCP leaders had done when embroiled in intraparty struggles. At the elite level, Mao's targets were the so-called Russian Returned Students led by Wang Ming (19041974), Bo Gu (1907-1946), and Zhang Wentian. These members of the party leadership had studied at the Soviet-sponsored Sun Yat-Sen University of the Toilers of China in Moscow during the 1920s. Through their work in the Comintern, they had developed close relations with the Soviet regime, which continued to exert influence over Chinese Communism, albeit with diminishing impact after rural insurgency became a main component of the project. Wang, Bo, and Zhang had each held the top post in the party before Mao's ascent. Each of them had lost a key ideological battle to Mao not long before he initiated the campaign. Known to be a Marxist theoretician and an essayist, Wang had promoted a Soviet-sanctioned model of a united front between the Guomindang and the CCP for the AntiJapanese War in lieu of the one proposed by Mao..$^{51}$ Zhang and Bo had headed the critical work of revolutionary propaganda and cadre training as well as the party organ Liberation Daily (Jiefang ribao), but encountered Mao's rebuke for failing to highlight the uniqueness of Chinese society and of the Chinese revolutionary experience. $^{52}$

Written by Mao shortly before Rectification spread across Yan'an, "Reform Our Study," "Rectify the Party's Style of Work," and "Oppose Stereotyped Party Writing" were important essays where he laid out the campaign's rationales and his dissatisfactions with particular types of conduct and thinking found under Chinese Communism..$^{53}$ Although the works unmistakably attacked revolutionaries who were well educated, none labeled Wang, Bo, Zhang, or any of the Russian Returned Students as petty-bourgeois or unreliable intellectuals. However, Mao's teeming complaints against party leaders and cadres who had researched, lectured, or written about Marxist theory and practice leave little doubt that he regarded the Returned Students as such subjects (rather than as proletarian revolutionaries like himself). In "Reform Our Study," Mao launched a thinly veiled attack against such individuals. He placed them together with other educated people within the party 
based on what he observed as their "subjectivist attitude" (zhuguan zhuyi) toward the socialist revolution and indicated why they all needed ideological reeducation.

With this attitude, a person does not make a systematic and thorough study of the environment, but works by sheer subjective enthusiasm and has a blurred picture of the face of China today. With this attitude, he chops up history, knows only ancient Greece but not China and is in a fog about the China of yesterday and the day before yesterday. With this attitude, a person studies Marxist-Leninist theory in the abstract and without any aim ... When making speeches, they [senior party cadres and even leaders] indulge in a long string of headings, A, B, C, D, 1, 2, 3, 4, and when writing articles, they turn out a lot of verbiage. They have no intention of seeking truth from facts, but only a desire to curry favour by claptrap. They are flashy without substance, brittle without solidity. They are always right; they are the Number One authority under Heaven, 'imperial envoys' [dispatched from Soviet Russia by the Comintern] who rush everywhere. Such is the style of work of some comrades in our ranks. ${ }^{54}$

Mao's attack against the Returned Students reminds us of Qu Qiubai's condemnation of Chen Duxiu and other CCP leaders during the late 1920s. That is, the victor of an intraparty struggle denounced the defeated as treacherous intellectuals. A critical difference, however, separates the attacks. Like Qu, the Returned Students had Comintern support and political training in Moscow. The fact that they became Mao's targets reveals that Soviet influence over Chinese Communism had declined significantly.

What happened to Zhang Wentian reveals how some defeated CCP leaders became self-denigrating "intellectuals" for others to see. A polyglot and a successful writer and translator, Zhang was one of the four Returned Students who had received advanced training in Marxist-Leninist thought from the Soviet regime. During the 1930s, he had used his training and leadership position to advocate passionately for the inclusion of "petty-bourgeois" writers and "intellectuals of petty-bourgeois background" in Chinese Communism. ${ }^{55}$ His appointment as head of the Academy of Marxist-Leninist Studies in Yan'an reinforced his superior status as a Marxist theoretician and revolutionary. As Mao's attack against fellow leaders intensified, Zhang conceded that the Returned Students were ideologically unprepared to be proletarian revolutionaries. In September 1941, he indicated at a high-level CCP meeting that the Comintern had made a grave mistake by placing "cadres without actual experience in revolutionary work" in the party's upper echelons. He confessed that "subjectivism" and "dogmatism" had severely colored his understanding of Marxist thought, leading to among other things his "crude and cartoonish" interpretations of issues and problems facing Chinese Communism. ${ }^{56}$ Responding to Mao's criticism and instruction, Zhang and other leaders embarked on a rural investigation trip in January 1942 to acquire what passed for genuine knowledge and experience about class and revolution in China. He and his team spent more than a year in northern Shaanxi studying and writing 
reports on economic and other village issues. His return to Yanan brought forth further self-reproaches. In a March 1943 report to the CCP Central Committee, he implicated others, too, as usable but unreliable intellectuals who lacked basic knowledge of Chinese society. "In particular," he wrote, "the kind of intellectuals like ourselves [who wanted a socialist revolution] always love to "hold our heads high and gaze at the sky' and find among the stars other-worldly, bizarre 'ideals' ... We do not understand the most mundane, most common, and yet most essential issue facing the masses," or their pains and traumas stemming from rampant class exploitation. ${ }^{57}$

Outside the CCP leadership, the Rectification Campaign in Yan'an targeted the large numbers of recently arrived "intellectuals" and led to conspicuous growth of ideological reeducation, mass surveillance, and management by party cadres. To be sure, the campaign also attacked those regarded as former peasants (nongmin) and workers (gongren) among the revolutionary personnel, or the purportedly deleterious impact of class exploitation on these persons' thinking and behavior. The assault on the intellectuals, however, occurred on an entirely different scale. First, the Mao regime had inherited from previous leaderships a deep distrust of such subjects. Second, recently arrived writers, artists, and students had incurred the ire of Mao and other leaders by airing or supporting complaints about inequality and other problems of organization in the town..$^{58}$ The leadership combined Marxist-Leninist and May Fourth language with Maoist reproaches and declared intellectuals an obstacle to revolution if they should remain ideologically unreformed. The attacks appeared widely in speeches, directives, and reports as well as in Liberation Daily, which also reproduced the required readings of the campaign. ${ }^{59}$ Many of the condemnations were drawn from Mao's writings, especially the above-mentioned essays; some were gleaned from other leaders' works, such as the notable piece written by Liu Shaoqi (1898-1969) in 1939, "How to Be a Good Communist." ${ }^{\circ 0}$ Mao's scornful remarks on intellectuals quoted at the beginning of this chapter constitute but one example of the torrential attacks.

The Mao regime claimed to have unmasked intellectuals' dubious participation in Chinese Communism on three levels: how they understood the project, what they wanted from it, and how they behaved in it. On the first level, the leadership charged that intellectuals glossed over the importance of Marxism and Leninism. Their political thinking reflected, instead, valorization of personal experience, fixation on abstruse philosophies, and dogmatic use of Marxist-Leninist teachings. That is, they failed to understand what Chinese Communism stood for. On the second level, the leadership noted that self-centeredness was a central trait of intellectuals. Although they were involved in a socialist revolution, they pursued their own goals, sang their own praises, and aspired to become famous surgeons, educators, writers, and so on, exhibiting en masse "the syndrome of a self-styled hero" (geren yingxiong zhuyi). This conduct of theirs harmed the project's progress. On the third level, intellectuals therefore tended to dislike assignments incompatible 
with their own ambitions or interests. They lacked discipline, flouted orders, and sought to come and go as they pleased. At heart, the leadership proclaimed, this focus on personal interests, accomplishments, and liberties reflected the "petty-bourgeois" or "bourgeois" backgrounds of intellectuals, or ways of thinking antithetical to sacrifice, order, and collectivism, the very things that Chinese Communism allegedly needed if it was to succeed. ${ }^{61}$

Within Yan'an, a multilayered instructional apparatus emerged, turning revolutionaries at virtually all levels into subjects of education as well as objects of knowledge. Headed by Mao, the ad hoc General Study Commission of the CCP Central Committee (Zhonggong zhongyang zhong xuexi weiyuanhui) handled policymaking. Subarea study commissions controlled by party leaders and senior party cadres appeared in the Red Army, the Central Party School (Zhongyang dangxiao), the Shaan-Gan-Ning government, and the cultural, educational, and other sectors. The commissions drew up study plans based on the leadership's instructions and on considerations relevant to the sector in question. Writers, teachers, military officers, government officials, and others underwent three to five months of training, using part of the workday to study and discuss material preselected by the General Study Commission. Mao and his deputies visited various establishments and gave lectures, advice, and encouragement. The trainees were required to "interrogate deeply," "discuss fervently," and "understand and connect with the spirit and substance" of the material. They had to use the material to examine the establishment where they worked and to "reform thoroughly" its operation and their colleagues' workstyles and political thinking. They were instructed to reflect "comprehensively" on their own conduct, ideas, and experience and to identify, examine, and overcome their political and ideological mistakes. Everyone, including senior party leaders, was required to keep "study and discussion notes" (biji), and to write and rewrite "a political history of the self" (zizhuan) to demonstrate efforts and progress. ${ }^{62}$

Besides serving to amplify the Mao leadership's attack on "intellectuals," topdown deployment of "criticism and self-criticism" across the many institutes engendered a multitude of supposedly firsthand confirmations of the official view. Under the supervision of senior or other party cadres, students and instructors divulged, discussed, and denounced their own mistakes and those of others. They condemned themselves and one another for selfishness, lack of discipline, arrogance, and other shortcomings that the leadership stated were common among intellectuals. They reported that they had been seduced by incorrect or impractical political views, including "dogmatic" interpretations of Marxism-Leninism. They traced the shortcomings to their own "petty-bourgeois" or other backgrounds and the allegedly corresponding lifestyles and social ties. Some pored through their own writings, drawings, or other works as well as those of one another, and discovered and decried objectionable political views and expressions. The authorities within the institutes organized the publication of some of the mistakes on wall 
posters, bulletin boards, and newsletters to encourage further collective learning and individual disclosure. Liberation Daily published select self-criticisms by writers, artists, and students for the same purposes. ${ }^{63}$

Additional mechanisms of official surveillance were set up to ensure the success of ideological reeducation. Before Rectification spread across the institutes and sectors, the General Study Commission had provided administrative and ideological training to senior party cadres to prepare them to become supervisors. During the campaign, the cadres attended study and discussion sessions at lower levels and offered instructions and guidance. The commission established a traveling inspection team (xunshi tuan) with responsibility of reporting once a week on general issues and concerns. Members of the team visited discussion sessions and gave recommendations. They had the authority to examine study and discussion notes and mete out tests to gauge the participants' efforts and progress. At lower levels, inspection commissions were formed, too, to monitor participation in learning activities. Members of these commissions assumed various tasks, such as attending discussions, administering exams, checking study notes, and giving advice. Some establishments (e.g., the Central Military Commission, the Central Party School, the Shaan-Gan-Ning Government) created visiting teams (canguan tuan) that traveled to other sites to exchange learning experiences. The team members would meet with senior cadres on the site, read study notes, and talk to individual participants. Some establishments (such as Shaan-Gan-Ning Government) even arranged joint conferences (lianxi huiyi) between various agencies to address campaign issues and assess progress. ${ }^{64}$

Within Yan'an, Rectification thus led to a "total reeducation of the [revolutionary] community." ${ }^{65}$ The intellectual as a classification of people doubled as a linchpin of the campaign and a substrate acted upon by it. Ideological reeducation, mass surveillance, and management by party cadres became the tripods and conduits through which the leadership normalized the meanings it inscribed on the marker and defined the authority structure of Chinese Communism. Henceforth, tens of thousands of revolutionaries recognized themselves or identified others as intellectuals based on the CCP discourse of class struggle. The objectification of the intellectual under Chinese Communism entered a new phase.

\section{MANIPULATIONS OF SOCIAL IDENTITY}

Although CCP domination produced in Yan'an a highly visible population of "intellectuals," its boundaries remained indeterminable in practice. The ambiguities embedded in the party's concept of intellectuals, the heterogeneous backgrounds of the revolutionaries, and the diverse training and opportunities they received ceaselessly affected how they regarded themselves and one another. Selfrefashioning, which intensified after Rectification, further blurred the boundaries of the objectified population. While relatively educated persons had to deal 
with actual or potential stigmatization, they also had opportunities to acquire positions and authority as government, industry, and other sectors expanded in nearby areas controlled by the party. This tension between class identity and revolutionary career, or the moral and the functional view of the intellectual of the Mao regime, drove many to monitor and even modify their own image. The fact that every indicator used by the party to define or describe the intellectual as a class subject (i.e., education, occupation, political thinking, moral dispositions, and habits and lifestyle) was changeable or concealable on an individual basis only reinforced self-refashioning.

Overall, four sets of hierarchical divisions that reflected the ideology and organization of Chinese Communism formed the basis on which Yanan revolutionaries sought to minimize stigmatization and benefit from their knowledge or skills. The divisions were those between the party elites and the rest of the revolutionary personnel, the military and the nonmilitary sector, "poor peasants" and "workers" and other Marxian categories of people, and party members and nonmembers. Since the 1920s, the CCP leadership had been investing the upper sections of these divisions with positive meanings, symbolisms, and imageries of class and revolution through speeches and statements, theater and literature, and other channels. An ascent to any of the upper sections would provide the revolutionary with symbolic resources for self-presentation, be they pertaining to his or her belief, behavior, or background. Upward mobility would not make one immune to being labeled an unreliable intellectual, as Mao's attack against Zhang Wentian and other Russian Returned Students evidenced. Nonetheless, the ascent would help the revolutionary separate herself symbolically, if not also physically, from the schoolteachers, journalists, and others working under Chinese Communism, for whom the leadership regarded ideological reeducation and discipline as most necessary, not to mention from the "petty-bourgeois" and "bourgeois" intellectuals outside the revolutionary project.

Based on memoirs and other material, we can divide Yan'an revolutionaries' strategies of self-refashioning broadly into three (non-mutually exclusive) types: self-consecration as proletarian revolutionary, deflection of the intellectual marker, and self-image makeover. As we have seen, self-consecration as proletarian revolutionary had been a strategy available to CCP leaders since the 1920s. The leaders exploited their revolutionary authority, organizational experience, and even literary skills to elevate themselves above the rest of the revolutionaries. The triumph of Mao during Rectification, and especially his attack against senior colleagues, greatly reduced the number of party leaders who could use the strategy. Timothy Cheek's study of the campaign offers clues to the kind of leaders who might still be able to present themselves as proletarian revolutionaries in words and deeds. Zhang Ruxin (1908-1976), Yang Shangkun (1907-1988), and Kang Sheng (18981975) had all studied in Moscow but had been supporting Mao before he initiated Rectification. During the campaign, Zhang, Yang, and Kang assumed leadership 
roles in the areas of propaganda, organization, and security respectively. Zhang and Yang reprimanded senior party cadres openly and instructed them on how to reform themselves ideologically; Kang was in charge of exposing and punishing "irredeemable enemies," including those among "intellectuals," and of delivering lectures to the cadres about such enemies ${ }^{66}$ Rectification thus elevated the three men above the cadres and even some party leaders. Equally telling is the case of the Red Army's commander in chief, Zhu De (1886-1976). Zhu came from a wellto-do family and had once enrolled in the University of Göttingen in Germany. By the late 1930s, a foreign correspondent observed, "Had it not been for his uniform, he could have passed for almost any peasant in any village in China." ${ }^{\prime 7}$ During Rectification, Zhu exploited his revolutionary authority, military leadership, and physical transformation to attack writers and others, including those within the army, for lacking proletarian consciousness. He indicated that he "did not belong to the proletariat originally" but "had handed himself over to" (toujiang) and was willing to die for that class. In effect, he announced that he was a proletarian revolutionary. ${ }^{68}$

For other CCP leaders chastised by Mao or subjected to ideological reeducation, Rectification did not necessarily lead to their permanent stigmatization as unreliable intellectuals. Quite the contrary, their superior status within the party provided them with otherwise unavailable opportunities to reclaim their proletarian revolutionary identity-so long as they submitted to Mao's leadership. Let us revisit Zhang Wentian's return to Yan'an from rural investigation. In the reports to the CCP Central Committee, he recounted repeatedly how he had studied work and life using Mao's ideological approach (which included "seeking truth from facts," "going to the masses," "emphasizing typical examples," and focusing on production), and how he strove to purge himself of the subjective, dogmatic, and bureaucratic attitudes that the Chairman had condemned. In December 1943 he produced for Mao's perusal a lengthy volume, Notes from Self-Examination (Fanxing biji), in which, to the Chairman's delight, he again "conducted a systematic and profoundly revealing criticism" of his intellectual habits and political mistakes. From then on, Zhang returned to the center of the party's activities, while continuing to criticize himself in public forums, including the Seventh National Congress of the CCP held in Yanan in 1945. His self-abnegation paid off. During the Congress, he was reelected to the Political Bureau, the party's highest body, which had only thirteen members. ${ }^{69}$ Zhang did not regain the political capital that he had once had as head of the party; nonetheless, he had enough compared with most others under Chinese Communism to present himself as a proletarian revolutionary.

At lower levels, Rectification amplified existing efforts by revolutionaries to deflect the intellectual marker. Some of the revolutionaries were from poor families and did not want their academic training or professional experience to impede their advancement. Ma Hong, with whom I began this chapter, was an example. 
For this precocious young man, the main challenge of self-presentation was how to draw attention to his disadvantaged background while benefiting from his excellent writing skills and education in a research institute run by the party. $\mathrm{Ma}$ emphasized his humble background and lack of schooling, and hence signaled that he was not another petty-bourgeois intellectual who had come to Yan'an to join the revolution. For revolutionaries like Ma, repeatedly referring to stints of manual labor that they had endured might help as well. What happened at the Anti-Japanese Resistance University during the late 1930s suggests that fingerpointing probably remained within the arsenal of self-representations of formerly underprivileged revolutionaries. When asked by superiors to screen and recruit recently arrived personnel into the party, some of the cadres staffing the campus balked. One of them remembers, "We were somewhat worried about absorbing into the party college students who used to wear long gowns and leather shoes. Almost all of those whom we had recruited until that point were young peasants or handicraft workers. I felt that those students did not behave as they should have in a revolution. Most of them had very complicated social ties and rather bad class backgrounds." ${ }^{\circ}$ The cadres exploited their familiarity with the CCP rhetoric of class and played up the social distance between themselves and the students, even as this gap was closing because of their own improving access to education and job opportunities, and because the austere lifestyle in Yan'an was continuing to transform the appearance, habits, and routines of the students. In effect, the cadres indicated to themselves and their superiors that they were genuine revolutionaries and the others were unreliable intellectuals.

Likewise, the CCP cadres who had survived the bloody purges of "intellectuals" in rural revolutionary bases during the 1930s had little reason to want to be marked as such subjects. By Rectification, some of these cadres had been in the countryside for more than a decade. The discipline, labor, and valor needed to survive armed invasions, severe climates, and demanding terrains had left physical signs, or (to borrow from Foucault) "a bodily rhetoric of honor"71 useful for self-presentation. For example, Long March veteran Cheng Fangwu (1897-1984), who headed the Northern Shaanxi Public Academy (Shaanbei gongxue) in Yan'an, was a May Fourth activist who had studied in Japan, taught in a university, and edited several journals, among other literary and intellectual activities. There was seemingly little in his everyday appearance that betrayed his superior education or previous privileges. As a former revolutionary recalls, Cheng was "of medium size, having a few whiskers and an always greasy face that he apparently seldom washed. He wore a cotton-padded jacket that looked filthy and glossy [from overuse]. Nowhere was Cheng close to resembling a cultured man [wenhua ren]; instead, he looked like a veteran cook." ${ }^{72}$ Yang Guangchi (1905-1987), a former college student, had been a political officer in Red Army forces since the early 1930 . In Yan'an, he trained large numbers of secondary school and college recruits at the Anti-Japanese Resistance University. A former student recalls that Yang was a 
"completely experienced soldier" who wore "shining five-star medals" on his uniform and hardships on his face and had "the appearance of an ordinary worker." ${ }^{73}$ Both Cheng and Yang adopted bodily strategies for self-presentation.

Self-image makeover was the most common strategy of refashioning employed by Yan'an revolutionaries after Rectification. Here stigmatized writers, students, and others performed commitment to the ideal version of a revolutionary as promoted by the Mao regime. Their goal was to gain symbolic and other resources that would help to alter their now-recognized identifications as petty-bourgeois intellectuals. Joining the Red Army was an approach for some, although a physically risky one. The CCP elites had built around the forces an aura of courage, loyalty, and discipline compared with the selfishness, impracticality, and other shortcomings ascribed to "intellectuals." Enlistment could bring one a military rank (such as platoon leader), a classification as military personnel (junren), and the accolade of "Red Army warrior" (hongjun zhanshi), all of which were symbolic assets. ${ }^{74}$ Serving in an impoverished village inside or outside the region as deputy village chief ( $f u$ xiangzhang) or village clerk (xiang wenshu) helped other revolutionaries to improve their images. The party needed staff to expand propaganda and organizational work in the countryside. Austere as life was in Yan'an, conditions in such villages were worse, filled with risks to health and life itself. ${ }^{75}$ By accepting a rural assignment, one practically announced willingness to rise above one's own "petty-bourgeois" desire for comfort and professional success. After Mao chastised writers and artists during the Yan'an Forum, many of them reportedly wanted to be sent to the countryside, or follow what the Chairman had asked them to do. ${ }^{76}$ The notable poet Ai Qing (1910-1996) and other artists as well as some former schoolteachers and students even volunteered to join the Red Army. ${ }^{77}$

The CCP authorities did not support every enlistment or transfer request from writers, artists, or students, and thus decided in practice which "intellectuals" would receive such opportunities for self-refashioning. Chen Xuezhao (19061991), an accomplished writer with a PhD from the University of Paris, had come to Yan'an in 1938. After Rectification, the authorities assigned her as an editor at Liberation Daily. Chen expressed her desire to live and work among poor villagers "to reform [her] thinking and worldview and to produce literary works that would serve peasants, workers, and soldiers." Her repeated requests for transfer to the countryside were denied. Two years later and not yet a party member, she was reassigned to the Central Party School as a literacy teacher. Headed by party leaders, this institute specialized in providing select cadres with advanced political training. ${ }^{78}$ Chen taught in the Fourth Division (Sibu). The enrollees were veteran cadres, military officers, and other cadres of "peasant" or "worker" origins who were chosen for their laudable service to Chinese Communism and their need for basic education for report-writing and other tasks. ${ }^{79}$ Within this environment, Chen could not but be typecast as an intellectual because of her background and responsibilities (see Figure 2). 




FIGURE 2. Commemorative inscription of Mao Zedong's message to college instructors counseling them to serve the revolution by fulfilling teaching responsibilities rather than by requesting to be sent to the frontline. (Photo by author)

Even writers, artists, and others who stayed in professional or literary posts after Rectification found ways to alleviate their stigma. The Mao leadership demanded that such revolutionaries improve their political consciousness and performance. Someone who received positive assessments in this respect from superiors stood a good chance of gaining a reassignment, an invitation to join the party, or a promotion in party rank-or symbolic resources for self-presentation. Displaying commitment to official ideology, watching one's words and deeds, and following orders were appropriate tactics. He Qifang (1912-1977) graduated from Peking University in 1935, and worked as a schoolteacher while publishing poetry and essays in newspapers before departing for Yan'an and joining the CCP during the late 1930s. When Rectification ended, the party decided to send him to Chongqing to liaise with novelists, essayists, playwrights, and others supportive of the revolutionary project. The city, which was in southwest China, had been designated by the Guomindang as the national capital. Hu Feng (1902-1985), a prominent writer among those who received He Qifang, remembered that the revolutionary used himself to illustrate the success of thought reform. He spoke with "a tone that 
made others feel he was proving he had already reformed himself into a genuine member of the proletariat," while indicating to his audience that they should mend their "petty-bourgeois" thinking and habits. ${ }^{80}$

Around the same time, Zhao Chaogou (1910-1992), a famous journalist who visited Yan'an with some others, noticed the following on his day of arrival: "Here the tinges of femininity are unusually light. Not even one woman wears a qipao [a close-fitting dress] or a perm, and no lovers strut around holding hands. Most female cadres put up little feminine affect and behavior (jiaorou de zuozuo). What they wear differs little from what male cadres wear. To exaggerate somewhat, Yan'an is probably the least sexy (xinggan) place [in China]." ${ }^{81}$ Such departures from the multifaceted display of urban styles and habits in the town before Rectification occurred in other areas of life, too. Zhao spoke to notable writers but found that they did not mention any foreign literary theory during conversations on art and literature, quoting, instead, Mao's famous lectures on the topics. Most of the students he interviewed had studied in urban schools and even colleges but showed no obvious sign of having received a Westernstyle education. The students gave "standardized" replies not only to queries about politics and revolution, but also to those related to romance and personal life. ${ }^{82}$ Their reactions undoubtedly reflected top-down pressure and tutelage and even fear. When considered with other flourishing tactics of self-refashioning, such conduct can be said also to reflect a desire to be seen as a committed revolutionary.

Participation in agricultural work, voluntary or not, was another channel for writers, artists, and other "petty-bourgeois intellectuals" to improve their own images. This form of adaptation had strong ideological, practical, and institutional support within Yanan. The CCP leadership had praised the class character of poor peasants and farm laborers, such as their perseverance, humility, and righteousness, even as their habits and dispositions were criticized as tainted by exploitative traditions. Driven by necessity, large numbers of revolutionaries had participated in agricultural production before Rectification. After the campaign, the Mao regime deepened what it called the "to the village" (xiaxiang) movement, requiring "intellectuals" to raise their revolutionary consciousness through working and living with peasants. The leadership expanded farming in the Shaan-GanNing base area to cope with Guomindang embargoes. Teachers, students, and others learned to sow grains, grow vegetables, raise livestock, chop wood, spin yarn, make tools, and so on. ${ }^{83}$ Shen Xia (1921-1945) was Mao Dun's daughter. She was attending Yan'an University, another institute started by the party, when she heard that the campus would participate in the drive to produce farm and other goods. What she entered in her diary suggests that production activities were perceived by those stigmatized as intellectuals as opportunities to alter their class identity: "Now it is time to experience reality and temper myself through labor. 
For someone who wants to train herself into a complete proletarian, genuinely taking part in labor has great import." ${ }^{4}$

In sum, Yan'an revolutionaries used occupational, physical, and linguistic strategies as well as institutional channels under Chinese Communism (e.g., official assignment, rank promotion, productive labor) to deflect the menace of the "intellectual" marker or mitigate its stigma. For these individuals, building a revolutionary career would entail managing their own biography, physical appearance, public conduct, social relations, and so on. The goal was to obviate or temper attacks against their political and moral character and garner approval from colleagues and superiors. As such, the maneuvers did not call into question the leadership's view of the intellectual as a usable yet unreliable subject. To the contrary, they further legitimized the view and objectified the intellectual.

In a 1990 lecture at the Collège de France, Bourdieu stated that if it seems easy to talk about a subject, it is because "we are in a certain sense penetrated by the very thing we have to study." ${ }^{5}$ The conviction toward what the subject is becomes an obstacle to understanding its genuine nature. The intellectual under Chinese Communism is a case in point. Research relies on readily available concepts of intellectuals that emphasize the social function, cultural capital, or moral conduct of the educated, however they are defined. The studies mask the metamorphosis of the intellectual from an obscure classification adopted by the CCP to concrete political, ethical, and physical forms, or embodied subjects locatable eventually throughout state and society. Within Yan'an, the emergence of a population of "intellectuals" reflected as well as affected the organization of Chinese Communism. The CCP discourse of class and revolution and reorganization of political relations, division of labor, and space constituted the ontological foundation of the subjects. As revolutionaries were turned into usable but unreliable intellectuals, ideological reeducation, mass surveillance, and workplace management by party cadres intensified. The incorporation of the intellectuals into the revolutionary project enabled the party to pursue otherwise unachievable goals, such as expanding industrial production, deepening rural mobilization, developing multifaceted propaganda, and increasing literacy in the Red Army.

What happened in Yan'an was but a harbinger of the mutual constitution of the intellectual and Chinese Communism that would occur nationwide. After 1949, class subjects recognized as intellectuals appeared in every sector penetrated by the state. The multiplications, elaborations, and intensifications of the ruling tactics and strategies that had originally converged in the town altered local organization and thus subjectivities and social identities. Government offices, newspapers, villages, and many other sites each had intellectuals who were used and abused 
in particular ways. Yan'an was the fountainhead of such development in another respect. The Mao regime assigned many revolutionaries who were trained there to positions of authority. Whether these cadres had been denounced as intellectuals by the regime or not, they were familiar with its ideology and practice of class struggle. They spread the official view of the intellectual through meetings, reports, newspapers, and other channels. They helped to reorganize local authority structures and install political control mechanisms. Some even headed scientific, educational, industrial, and cultural establishments. In short, they became frontline agents in the objectification of the intellectual under the PRC. 